\title{
Health, disability and work: patterns for the working age population
}

\author{
Pilar García-Gómez • \\ Hans-Martin von Gaudecker • \\ Maarten Lindeboom
}

Published online: 18 August 2010

(C) The Author(s) 2010. This article is published with open access at Springerlink.com

\begin{abstract}
We examine the role of health as a determinant of labour force participation, paying particular attention to the link between the two provided by disability insurance schemes. We first review the evidence on associations between health and labour force participation. Enrolment in disability insurance is not determined by health alone, and we highlight the main other causes that the literature has identified. In an application to The Netherlands, we follow the structure of the literature review and show that the trends in health and disability insurance enrolment look rather positive. In particular, the 1990 reforms of disability insurance might have been more effective than previously realised because part of their success was hidden by demo-
\end{abstract}

This research was funded by Stichting Instituut GAK and Netspar. The authors would like to thank Amco Wiering for excellent research assistance and Philip de Jong, Rob Euwals, and Jan-Maarten van Sonsbeek for useful comments regarding the Dutch Disability Insurance system. Three anonymous referees and seminar and conference participants at the Netherlands Bureau for Economic Policy Analysis (CPB), the Netspar Annual Conference "Rethinking Retirement", and the October 2009 Netspar Panel-particularly our discussants Daniel van Vuuren, Katherine Carman, Wim Groot, Philip de Jong, Gijsbert van Lomwel, and Marc Koopmanschap—provided many comments that greatly helped to improve upon the paper.

P. García-Gómez

Erasmus University Rotterdam, Rotterdam, The Netherlands

H.-M. von Gaudecker $(\bowtie)$

Universitat Mannheim, Mannheim, Germany

e-mail: hmgaudecker@gmail.com

M. Lindeboom

VU University Amsterdam, Amsterdam, The Netherlands

M. Lindeboom

IZA, Bonn, Germany

P. García-Gómez · H.-M. von Gaudecker · M. Lindeboom

Netspar, Tilburg, The Netherlands 
graphic change: The large number of baby boomers kept the absolute inflow high as they aged, despite large reductions in relative rates.

Keywords Health · Disability · Disability insurance $\cdot$ Labour force participation

JEL Classification $\mathrm{J} 2 \cdot \mathrm{I} 1 \cdot \mathrm{J} 08$

\section{Introduction}

Most developed countries are currently encouraging later retirement in order to mitigate adverse effects of ageing populations. The Netherlands have been very successful in raising the participation rate of older workers in the past decade. Labour force participation rates of men aged 55 to 64 increased from $41.8 \%$ in 1994 to $62.7 \%$ in 2008 and female figures more than doubled from $18.5 \%$ to $42.5 \%$ over the same period (OECD 2009). Various measures mainly targeting the abolishment of work disincentives have boosted employment rates of individuals up to their late fifties above the OECD average. Recent policies are expected to lead to further increases in the participation rates of older workers. The scope for their success is in part determined by participation rates of the middle aged. At least in the European context of labour demand it is unlikely that individuals who left the labour force years earlier will be induced to return by policies focussing on incentives to work. Despite the recent success in raising labour force participation rates of older workers, these rates continue to fall rapidly after age 45-for example, in 2007 they were $89 \%$ for men in their late forties and less than $79 \%$ for men in their late fifties. Understanding the sources of the relatively early drop in employment rates is thus of crucial importance in order to continue the success of earlier policies.

Poor health is arguably the most important reason for very premature labour force exits. There is abundant evidence demonstrating a positive association between health and labour market status. But the relation is complicated by all kinds of factors typically encountered in applied work. They include reverse causality (work conditions impact health), simultaneous determination of health and work outcomes (among others, preferences and cognitive ability drive health investment and labour supply decisions), measurement error (there is no single appropriate measure of health), and left-out variables which are difficult to observe (such as good measures of education). It becomes even more complicated when considering the social security program targeting those not able to work because of health reasons: The literature has identified many determinants of enrolment in disability insurance (henceforth DI) programs other than health (like the state of the business cycle or changing financial incentives). Such obstacles lead to the somewhat paradoxical situation that despite a large number of studies, clear-cut policy recommendations are hard to formulate.

In this paper, we attempt to summarise the existing evidence from the developed world and provide some dedicated analyses for The Netherlands. We start out in Sect. 2.1 by reviewing the findings of the international literature on the relationship between health, limitations to engage in activities of daily living, and employment. Most of the literature is descriptive, but some careful studies re-assure common sense 
and demonstrate that part of the relationship between health and work is indeed due to poor health leading to lower labour force participation rates. While one may be led to think that the problem will be ameliorated because ever increasing longevity implies similar decreases in morbidity, Sect. 2.2 demonstrates that these trends do not always go hand in hand. The contemporaneous situation in the U.S. is the most prominent counterexample. We then review the evidence on determinants of DI enrolment. The literature convincingly shows that the changes observed in the size of the U.S. DI system have little to do with underlying population health.

In Sect. 3, we then turn to The Netherlands. We show that overall trends in population health are positive. At the same time, policy needs to focus on those in ill health because there is hardly any potential for raising employment rates among healthy (non-disabled) 50 year olds. Disability insurance has been very prominent in The Netherlands, which had one of the most generous systems in the world for many years (Bound and Burkhauser 1999). We briefly describe this system and the many changes that it underwent since the early 1990's, which culminated in a major reform taking effect in 2006. Because the total number of enrollees grew or stayed constant, the earlier reforms were generally regarded as unsuccessful. We show in Sect. 3.3 that demographic change was the main driver of these constant rates-relative enrolment dropped significantly for each younger cohort conditional on age, but at the same time the labour force grew significantly older. An exception to this pattern is found for very recent years in the program for the young disabled, which we treat separately in Sect. 3.4. Finally, Sect. 4 discusses the relevance of our findings and those of the literature for policies that aim at increasing labour market participation rates of older workers.

\section{Health and labour force participation: previous evidence}

\subsection{Health and labour force participation: associations and impacts}

Currie and Madrian (1999) review a large body of literature linking health, health insurance and labour market outcomes. They conclude that the evidence suggests a strong positive relation between health and labour, and that indeed ill health seems to be negatively related with all labour outcomes, i.e., wages, earnings, labour force participation, hours worked, retirement, job turnover, and benefit packages. The evidence is particularly sound for older workers and the correlation is stronger for employment than for earnings. These associations are, however, difficult to interpret. As discussed in the introduction and stressed by Lindeboom (2006), work outcomes at later ages are the result of previous health and labour outcomes, so not only health may be endogenous in a labour supply model but also other measures, such as financial incentives. In addition, health and work are jointly determined. Therefore, in order to disentangle the causal effects of one measure on the other we require independent variation in one of the variables or assumptions on the structure of the model.

Two recent studies have used accidents as unforeseen sudden changes in health to identify the causal effect of health shocks on labour market outcomes. Using Danish register information, Møller Danø (2005) analyses the effects of having a road accident that requires hospitalisation on annual employment rates up to 6 years after the 
accident occurs. She finds that the employment rate of injured men decreases sharply after the accident by about $10 \%$. It does not recover to the level of the comparable group after 6 years.

Lindeboom et al. (2007) confirm the existence of long-run effects of an accident on labour outcomes using British data. They show that having an accident does not have a direct effect on employment if the individual's health status remains unchanged, but accidents increase the probability of the onset of a disability by $172 \%$ in the shortrun, and some effects are also observed in the long run. In addition, they find that the onset of a disability at age 25 reduces the employment rate at age 40 with around 14 percentage points. This is about two thirds of the gap between the employment rate of disabled and non-disabled workers. The remaining third of the employment gap is due to differences in background characteristics.

Using propensity score matching techniques, Lechner and Vazquez-Alvarez (2004), García-Gómez and López Nicolás (2006), and García-Gómez (2008) come to broadly similar conclusions for a total of eight European countries. Careful econometric studies thus confirm the intuition that health deterioration worsens the labour outcomes of young, middle-aged, and old workers; and that many effects do not vanish over time. Hence, it is meaningful to consider the broad trends in population health and disability as a necessary prerequisite to changes in the labour force participation.

\subsection{Trends in health and disability}

Looking at the ever increasing average human lifespan in the developed world (Oeppen and Vaupel 2002), one may be tempted to think that this trend goes hand in hand with similar decreases in morbidity. However, prevalence rates of ill health and disability remain high at relatively young ages. For instance, in the UK around 5\% of the 20-24 year olds has a long standing disability and this number increases to around $13 \%$ for the $40-44$ year old and to $28 \%$ for those aged 55-59 (Berthoud 2008). Similar disability rates prevail in the U.S. and for The Netherlands these numbers are even higher (Kapteyn et al. 2007). So what are the long-run trends of these variables for the working age population?

Several studies provide analyses of the disability trends in the U.S. from the 1980s to the late 1990s (for example Crimmins et al. 1999; Lakdawalla et al. 2004; Bhattacharya et al. 2008). The evidence suggests that while prevalence rates for individuals older than 60 have decreased, the rates for younger age groups have seen no improvement or even an increase.

Bhattacharya et al. (2008) go into more detail and decompose trends in disability among working age populations between 1984 and 1996, thereby separating two factors driving observed trends: The prevalence of chronic diseases and the fraction of disabled individuals among those with a chronic condition. They find that disability increased among 30 and 45 year olds and decreased for 60 year olds. The increase for the younger age group was partly due to a higher prevalence of chronic disease (40\%) and partly due to changes in disability prevalence among those with a condition $(60 \%)$. Among the 60 year olds, disability rates fell even though the prevalence of chronic conditions increased. This means that disability prevalence among those 
with a chronic condition has fallen substantially for the 60 year old. They further show that the rising prevalence of obesity has been an important source of the rise in disability prevalence.

Lakdawalla et al. (2004) find that the rise in reported disability among younger Americans cannot be explained by changes in the composition of the population as disability was rising for whites and non-whites, for those inside and outside the labour market and for all education groups. They suggest some possible explanations for rising disability levels, such as obesity, changing DI laws, or technological advances in medicine. The latter would allow frail individuals to live longer than without such progress. Thus, for a cohort analysis of trends in health and disability it is important to take mortality into account.

The literature summarised in this section shows that increases in longevity do not necessarily translate into decreases in morbidity. We will analyse these trends for The Netherlands in Sect. 3.1. In the U.S., the prevalence of both chronic conditions and disabilities are increasing among the cohorts whose members are up to 50 years of age now. By itself, this trend would suggest lower labour force participation rates and higher rates of enrolment in disability insurance programs in the future. However, the literature has identified many more factors that are driving enrolment in DI programs.

\subsection{Non-health determinants of DI enrolment}

The majority of relevant studies comes from the U.S., where about $80 \%$ of the working age population is insured against the risk of being unable to work because of physical or mental disability by the Social Security Disability Insurance program (SSDI) program. In 1985, about 2.2 percent of the working age population received SSDI benefits. Since then, this number has almost doubled. The employment rate of the working age population with a limiting health condition fell from $80 \%$ in 1970 to $60 \%$ in the beginning of the 1990 's, whereas the employment rates of individuals without such a condition remained constant (Bound and Waidmann 2002; Bound and Burkhauser 1999). Both Bound and Burkhauser (1999) and Autor and Duggan (2006) examine the factors that are responsible for the growth in SSDI rates. Autor and Duggan (2006) consider four potential determinants: (i) changes in the DI screening process; (ii) rising financial incentives to apply for DI; (iii) changes in labour force participation that increased the size of the insured population; (iv) changes in health and the age structure of the population. They argue that the first factor is most important contributor. Prior to 1984, eligibility depended on an applicant's objectively verifiable medical condition that had to exceed a minimum threshold. In that year, a reform enlarged the medical criteria with an applicant's ability to function in the setting of a workplace. Furthermore, the legislative changes required that evidence from the applicant's own health care provider should be taken into account, provided that this was not at odds with other medical evidence, leading to more scope for appeals. In the years prior to the reform, about $84 \%$ of the initial awards were strictly based on medical criteria. By the year 2000, this number had fallen to merely $40 \%$. This trend was accompanied by a shift in the importance of diagnosis groups: The number of new awardees with musculoskeletal conditions (most prominently: low back-pain and arthritis) and mental disorders grew by $323 \%$ 
between 1983 and 2003, whereas the corresponding increase in cancers and heart diseases was only 30\% (Autor and Duggan 2006). These figures are common to other OECD countries, where an increase in the importance of the share of mental problems has also been observed (OECD 2008).

Duggan and Imberman (2006) show that changes in population characteristics have played a minor role in the DI enrolment increase. Ageing was a minor factor because at the time of their analysis, the baby boom generation had yet to reach the ages in which inflow into DI is most prevalent. The increased number of women in the labour force could only explain about a sixth of the total increase in DI receipt among women. Bound and Burkhauser (1999) summarise the literature on the relationship between SSDI benefit generosity and SSDI application rates. They conclude that increases in SSDI benefit levels have lead to strong increases in SSDI applications. Following up on this, Autor and Duggan (2003) find that DI application and recipiency rates of low skilled workers became two to three times as responsive to aggregate demand shocks. This finding is line with Stapleton et al. (1998), who show that recessions contributed in an important way to the growth in SSDI. Indeed, structural changes in the labour market may have affected the employment opportunities for low skilled workers and this may also have led to an increase in the SSDI rolls (Black et al. 2002).

Indeed, there is some direct evidence that DI programs interact with other programs of the Social Security and Welfare system. Kreider and Riphahn (2000) show that the decision to apply for SSDI benefits also depends on employment opportunities and on unemployment insurance benefit levels. Riphahn (1999) and Kerkhofs et al. (1999) find evidence for substitution between disability programs, unemployment programs and early retirement programs. Banks et al. (2007) find that financial incentives are important determinants of transitions into retirement for men aged 50 to 59 in the UK, while poor health plays a more important role in transitions into other types of inactivity. In the above-cited study by García-Gómez (2008), she shows that several cross-country differences in employment probabilities and disability insurance take-up following a health shock can be attributed to differences in social security arrangements.

\section{Health and labour force participation: the Dutch experience}

The results from the previous section suggest that future labour participation rates in The Netherlands will depend both on health trends and on the success of recent DI reforms. In this section we first analyse the health and labour force participation trends observed during the past 20 years. We then describe the Dutch DI system and review the major changes it underwent recently. Finally, we relate the trends in DI enrolment to the changes in health and reform efforts, closing with some notes on a special DI scheme for the young.

\subsection{Trends in health and work}

Similar in spirit to van Kippersluis et al. (2010), we describe trends in health and disability in The Netherlands, using a health and general-purpose household survey 

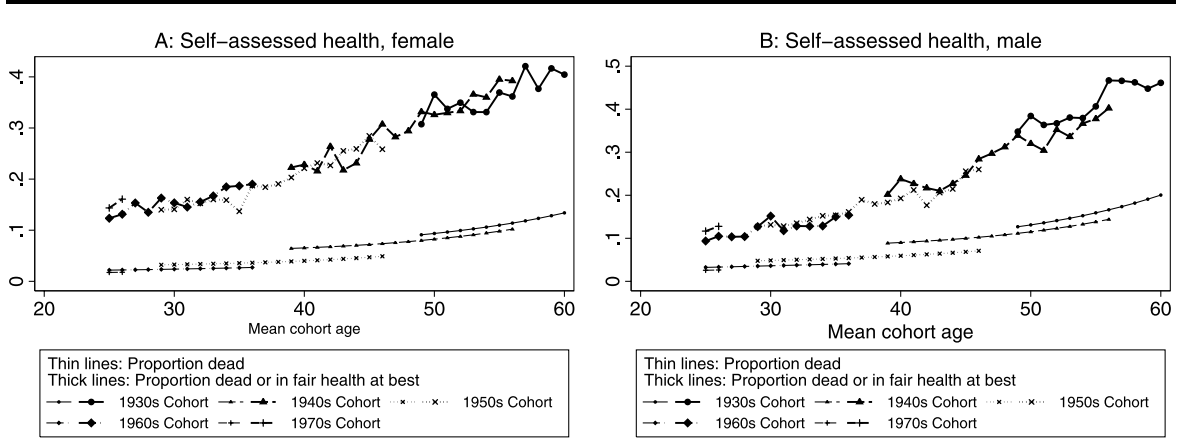

Fig. 1 Fraction deceased or in ill health by cohort and age. Source: Gezondheidsenquête / POLS, own calculations. Also see the Appendix

made available by Statistics Netherlands. We describe it in detail in the Appendix. Having about 20 years of data available, we describe the health experiences of cohorts defined by gender and birth decade. We include cumulative mortality rates directly in our graphs, using data from the Human Mortality Database (HMD 2009).

Figure 1 depicts the probability to report ill health (defined as rating one's health as is fair, variable or poor on a 5-point scale) for different age groups and cohorts. The thin lines present the cumulative fraction of deceased individuals. The secular improvements in mortality are immediately apparent. The most remarkable improvement can be seen between the cohorts born before and after 1950. Earlier cohorts have much higher mortality rates at any given age. The fraction deceased at age 50 can be as high as $9 \%$ for females and $13 \%$ for males. At age 60, $20 \%$ of the entire cohort of males are deceased. Furthermore, the fraction of individuals in the ill health category increases from around $10 \%$ at age 25 to more than $40 \%$ at age 60 (males). No clear differences in self-reported health can be found for the different cohorts.

Figure 2 reports the fraction of people with a disability. A disability is defined as an impairment that limits activities of daily living (ADL). The variable we use is an indicator that equals one if an individual has more than 3 light or more than one severe limitation, for details see the Appendix. While this is not directly measuring work disability, it is of immediate importance and does not suffer from the fact that the answers to direct work disability questions often depend on the respondent's profession. The figures show that disabilities show up at relatively young ages and that at age 50 already $20 \%$ has limiting conditions. The U.S. pattern of rising disability rates among younger cohorts does not appear to be true for The Netherlands. If anything we find the opposite pattern, particularly among the older cohorts in our sample.

Figures 3 and 4 show individuals' labour market status by their self-reported health and by suffering from a limiting health condition, respectively (both health variables as defined before). Those with worse self-reported health and those with limiting conditions have much lower employment rates. More specifically, of the 50 year old males who report to be in ill health only about $40 \%$ is at work. For 40 year old men the employment rate is around $60 \%$. For females these numbers are lower. The most important feature of the graph is that employment rates are very close to one for men in good health / without a disability well into the fifties. In other words, the potential of increasing the participation rates in these groups is very low. Bad health remains 
In two respects the results from this section are important ingredients to an analysis of disability insurance in The Netherlands. First, practically all prime-aged people without a health problem work. This emphasises the importance of considering in detail the incentive structures for individuals in ill health, which are primarily shaped by DI schemes. Secondly, we have seen that conditional on mortality and age, there are relatively small health differences between cohorts. Major differences in DI enrolment among cohorts may thus be attributed to other factors with reasonable confidence.

\subsection{DI in The Netherlands: continued reform efforts}

Much of the discussion in this section follows the papers by de Jong (2008) and de Jong et al. (forthcoming). Since the 1930s The Netherlands had a sickness benefit act and a work injury scheme to cover earnings losses due to sickness and disability. The WAO ('Wet arbeidsongeschiktheid') was introduced in 1967 and integrated the two pre-exiting schemes to cover earnings losses due to all disabilities, whether work related or not. The WAO had a one year waiting period during which workers were entitled to sickness benefits. Most fully disabled individuals received $70 \%$ of predisability earnings until the statutory pension age of $65 .^{1}$ In the early 1990 's, almost $5 \%$ of the Dutch GDP was spent on DI (OECD 2008), leading to various reform efforts that culminated in 2006 with the introduction of a completely new system ('Wet werk en inkomen naar arbeidsvermogen' or WIA).

Between 1993 and 1995, some smaller measures were taken which attempted to reduce DI benefits and to enforce more stringent medical eligibility criteria. At the same time, the employers' financial responsibility for sickpay increased. In 1996, the latter was extended and employers were made fully responsible for sickpay during the waiting period. In 1998, experience rating ("the polluter pays") was introduced. For every worker awarded a DI benefit, his or her firm's contribution rate increases. Conversely, the rate is lowered if a firm hired a DI recipient.

As of April 2002, the so-called gatekeeper protocol became effective. In this protocol the responsibilities of a sick employee, his/her employer, and the company doctor are legally specified. The protocol mandates a structured approach to early intervention in cases of sickness, enforcing major reintegration efforts by both employer and employee over a period of almost two years. ${ }^{2}$ In 2004 , the mandatory waiting period was extended from one year to two years.

The WIA regime started in 2006 and has two different types of benefits: the IVA benefit for the full and permanently disabled and the WGA benefit for partial or tem-

\footnotetext{
${ }^{1}$ Starting in 1994, the DI benefit period was cut in two chronologically linked parts. The first was a shortterm wage-related benefit replacing $70 \%$ of before-tax earnings. The duration of this wage-related benefit depends on age at the onset of disability. It varies from zero for those under age 33 to six years for those whose disability started at age 58 or beyond. The second part is a so-called follow-up benefit with a lower income base. This earnings base is the minimum wage plus a supplement depending on age at onset according to the formula: $0.02 \times$ [age at onset -15$] \times[$ wage - minimum wage $]$. However, most collective bargaining agreements covered the gap between the lower benefits in the follow-up period and the wage-related benefits in the initial period of disability.

${ }^{2}$ de Jong et al. (forthcoming) describe this process in much more detail.
} 
porary disability. The degree of disability is determined by a disabled worker's (residual) earnings capacity. This earnings capacity is derived by considering the earnings from any job commensurate with one's residual earnings capacity, relative to the current earnings. The degree of disability is then defined as the complement. A claimant is awarded an IVA benefit if the capacity loss is $80 \%$ or more and there is no potential for any degree of recovery. An IVA benefit is $75 \%$ of previous gross earnings. A worker is awarded a WGA benefit if the capacity loss is between $35 \%$ and $80 \%$ or more than $80 \%$, but with prospect of recovery. The WGA benefit is cut in two chronologically linked parts. First, a short-term wage-related benefit replaces $70 \%$ of the difference between the pre-disability wage and the new wage if the worker continues to work; or $70 \%$ of the pre-disability wage if he or she is out of the labour force. The level of the subsequent benefits is determined by the extent to which a disabled person uses his or her residual earnings capacity. The WGA remains the same if the full work capacity is utilised. When only part of the residual work capacity is used, it is considerably lower. This underlines the emphasis on work in the current WIA program.

Because of the work requirements imposed by the programs analysed above, individuals who became disabled in their childhood or youth and never had a chance to work cannot access this system. A special program was introduced in 1976 and it is known under the acronym Wajong ('Wet arbeidsongeschiktheidsvoorziening jonggehandicapten'). It is financed from general tax revenue and currently pays a benefit of $75 \%$ of the minimum wage in case of a work impairment that reduces one's earnings capacity to below the minimum wage. A successful application requires proof that the disability was present on the individual's 17 th birthday, or before his or her 30th birthday if he or she was involved in an educational program at the time of onset. As the DI system, the program is administered by the National Insurance Board ('Uitvoering Werknemersverzekeringen', henceforth UWV). Because the Wajong program and the WAO/WIA system differ in the population insured, the benefits calculation, and the job requirements, we will analyse the trends separately.

\subsection{Empirical trends in Dutch DI: more light than expected}

As described in de Jong et al. (forthcoming), there was a sharp increase in the percentage of individuals collecting DI benefits after 1970, with numbers doubling from four to eight percent until 1985. After a short period of stagnation, inflow increased again in the late eighties and early nineties, triggering the reforms described above and leading to reduced inflow rates for several years. Furthermore, between 1994 and 1996 part of the stock of beneficiaries was reexamined using the new, more stringent, eligibility rules. As a result the number of benefit terminations grew sharply and, on balance, led to a $7 \%$ drop in the number of beneficiaries. From then on, the numbers started growing again.

DI Inflow rates decreased strongly in the period 2001-2006. Two changes in the WAO system may have been important for this. First, the introduction of experience rating of employer DI premiums may have been important. Koning (2009a) argues that the effect of this experience rating came much later and has contributed to the sharp decline. Second, research has indicated that about half of the reduction in the 
inflow rate was due to the introduction of the gatekeeper protocol described above (de Jong et al. 2005). An important element of this gatekeeper protocol was the introduction of stricter screening of DI applications. de Jong et al. (forthcoming) find that the stricter screening of the DI application files reduced disability insurance applications by $5 \%$. Furthermore, stricter screening does not appear to have resulted in spillover effects on the inflow into unemployment insurance. This result is in line with findings for the U.S. (Parsons 1991).

The numbers above include partial WAO beneficiaries. Two thirds of partial benefit awardees work. For them, and their employers, the benefit acts as a wage subsidy. de Jong and Thio (2002) show that partial beneficiaries differ from full beneficiaries in many respects: They are older, better schooled, more often male, married and main breadwinner, have a longer tenure with their current employer and work in large, financially healthy firms. In short, Dutch partial beneficiaries are socially and economically better off. It is also suggested that partial benefits are often used to offer older employees easier work conditions and act as a partial early retirement scheme. Depending on the assessment process, this may be a good strategy to enable persons with a health problem to work. However, de Jong and Thio (2002) provide evidence that this was not always the case in The Netherlands. Given the data at hand, it is out of the scope of this paper to provide additional analyses. In what follows, we concentrate on full beneficiaries and we refer the reader to de Jong and Thio (2002) for a comprehensive assessment of partial DI recipients.

Figure 5 shows the proportion of cohorts on disability rolls. ${ }^{3}$ First consider the picture for males (Panel B). As expected, the proportion of beneficiaries increases with age. The slope is particularly pronounced for the 1930s cohort, whose late working life fell into a recession, suggesting DI as an exit route from the labour market (see also Black et al. 2002). Very large cohort effects are immediately apparent, with older cohorts having much higher rates of persons on the DI rolls. This is likely to reflect both the institutional changes that we have just described and work conditions that shifted away from physically strenuous work for many persons. There is already a sizable fraction of relatively young individuals on DI benefits, although it is reassuring to note that this fraction decreases for younger cohorts. Unfortunately, the pre-2000 IPO data do not allow us to discriminate between various DI programs. Hence, Fig. 5 also includes Wajong benficiaries, whom we will cover in detail in the next section.

Except for the age gradient, the picture for women (Panel A) is completely different and reflects the large increases in female labour force participation among younger cohorts. Conditional on age, younger cohorts always have higher proportions of beneficiaries than do older cohorts. For those born in 1960 and later, we already observe higher beneficiary rates for women than for men-which is not much of a surprise, given the substantial female labour participation rates and the gender differences in health and disability observed above and elsewhere (Case and Paxson 2005).

Comparing the situation in The Netherlands to the one in the U.S. described in the previous subsection, the only similarity is that underlying population health did not

\footnotetext{
${ }^{3}$ The proportions are derived from the 1989-2005 IPO (Inkomens Panelonderzoek) data which is based on tax registers. Comparison at the micro level with the 1998-2005 SSB_AO (derived from the DI administrative records) show that these are likely to be (slight) underestimates.
} 

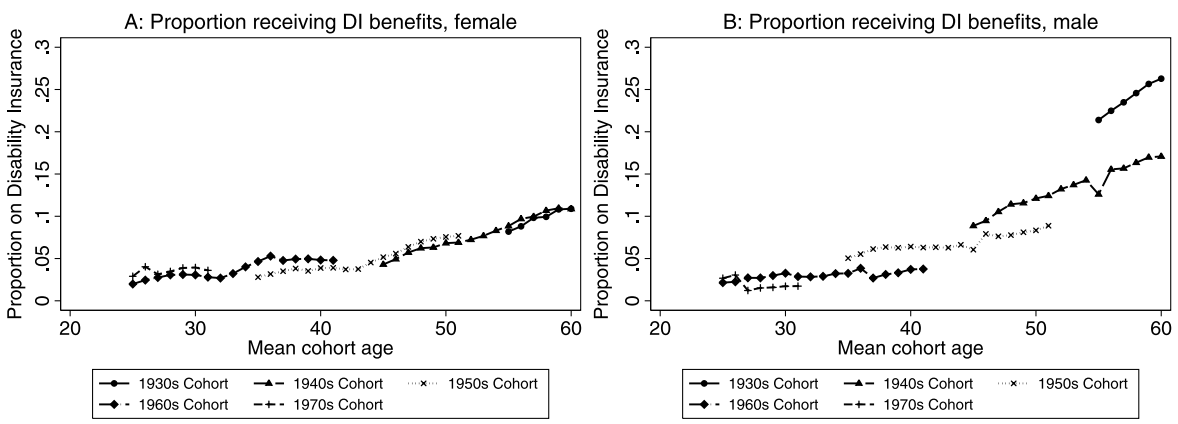

Fig. 5 Fraction receiving DI benefits by cohort and age. Source: Statistics Netherlands Microdata (IPO), own calculations

seem to play a major role for DI enrolment in either case. We have shown in Sect. 2, that contrary to the U.S. situation the health prospects of younger cohorts do not seem to worsen, either. It appears that the various reforms after 1990 were effective in drastically reducing younger cohorts' enrolment rates. However, this success was hidden in the aggregate numbers by demographic factors: The large number of baby boomers kept the absolute inflow high as they aged-despite the large reductions in relative rates.

Figure 6 permits another look at the effect of business cycles on alternative insurance mechanisms and exit rates from the labour market. Because of the large secular changes for females, we limit ourselves to men. We use a five-year definition of cohorts and show only every other cohort for legibility reasons. Panel A depicts the fraction of beneficiaries receiving benefits from either disability insurance, unemployment insurance, or general social assistance (bijstand). For the younger cohorts, the number of benefit recipients is highest in the early and mid-nineties (which was a recession period) and declines subsequently. For older cohorts, it rises almost unambiguously with age. What is interesting now is the breakdown on the three types of benefits that can be seen from Panels B-D. For the 1930-1934 and the 1940-1944 cohorts, the bulk of both the stock and the increase in benefits is made up by disability insurance. The recipients appear to be out of the labour market for good, even if economic conditions get better. The fraction of unemployment insurance recipients of the 1940-1944 cohort, however, experienced at least a small drop in the late 1990s, without a similar increase in social assistance benefits. For younger cohorts, most earnings insurance went through unemployment benefits and social assistance, which strongly moves with the business cycle. A tentative conclusion from the graphs that still awaits a formal analysis (although the job search literature and the much lower search incentives for DI recipients compared to UI recipients are suggestive) might thus be that DI has much more permanent effects on the labour force participation than does UI. ${ }^{4}$ Corroborative evidence comes from Koning and van Vuuren (2010), who examine the degree of substitution between DI and UI schemes in The Netherlands. They find that between 1993 and 2002, about 3\% of all dismissals took place

\footnotetext{
${ }^{4}$ The analyses for the older cohorts have to be taken with a grain of salt since we do not see early retirement benefits in these graphs.
} 

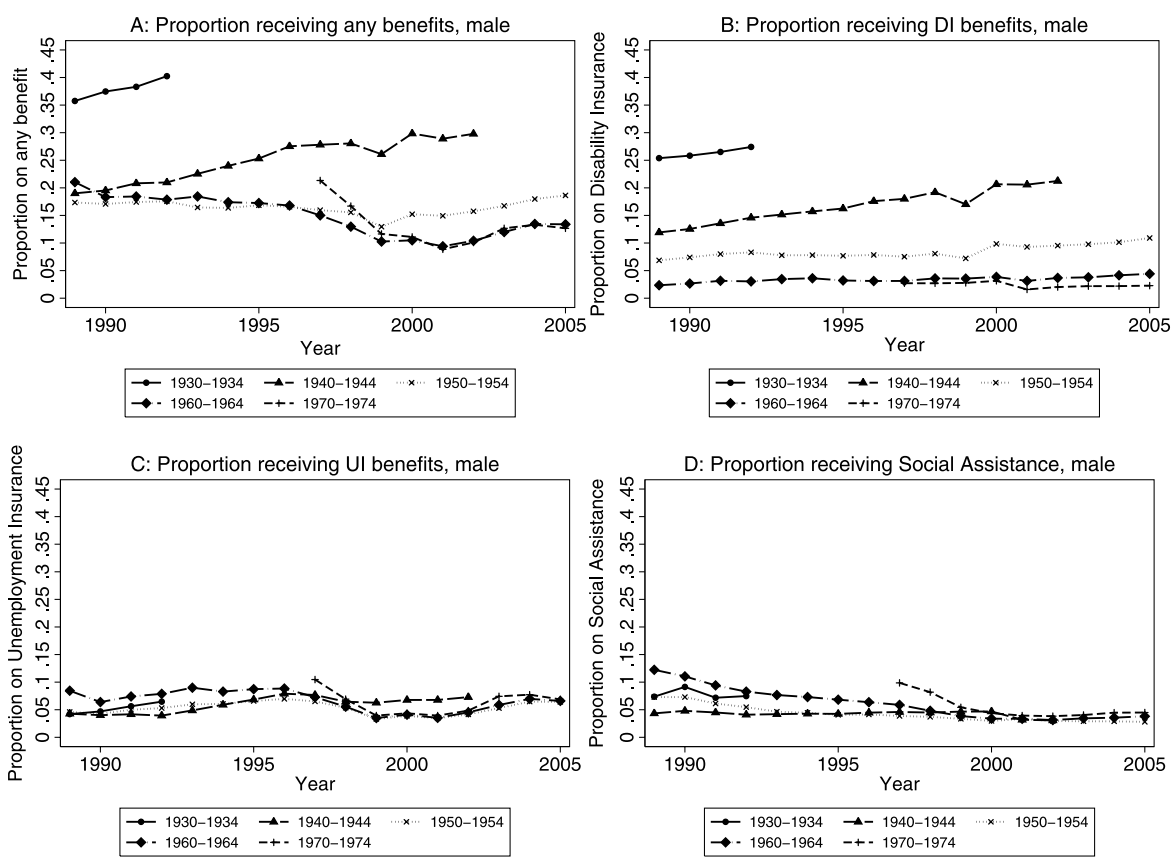

Fig. 6 Fraction of men receiving Social Security Benefits by cohort and year. Source: Statistics Netherlands Microdata (IPO), own calculations

via DI. This implies that about a quarter of all DI enrolments observed in their sample consists of hidden unemployment.

Our data do not reach far enough into the present as to permit an evaluation of the WIA introduction. But we can summarise some trends published by the UWV. There was dramatic fall in the number of applications. The number of WIA assessments in 2006-2008 was in the order of 35,000 cases per year, which is well below the approximately 100,000 cases that were assessed in the old WAO system in the years 2000-2002. These numbers should not be taken at face value because of the extension in the sickness pay period noted earlier, but this alone cannot explain the entire reduction. About 55\% was awarded a benefit and the rest of the applications was denied because the loss in earnings capacity was assessed to be below $35 \%$. Only around $20 \%$ of awards were IVA benefits (fully and permanent disability). Of the WGA-beneficiaries, about $60 \%$ were assessed to be fully disabled, but with some prospect for work in the future. The employment effects are difficult to assess directly, but these can be substantial as it appears that the large drop in applications did not translate into higher unemployment rates. However, the labour market conditions were very good for the period where data was available and this might change in the near future.

3.4 The Dutch DI scheme for the young disabled: some shadows?

Contrary to the trend for the WAO/WIA, the Wajong program experienced substantial growth in both absolute and relative terms. The number of beneficiaries sur- 

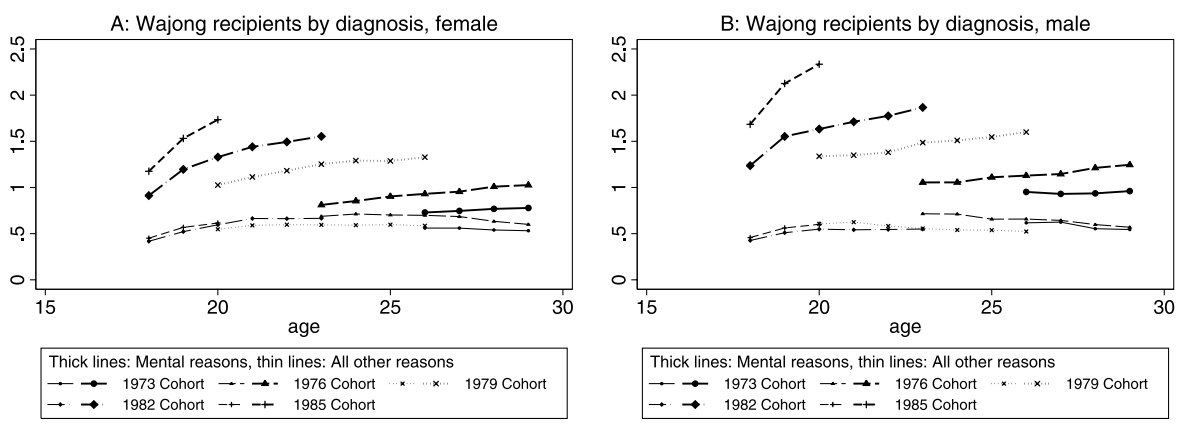

Fig. 7 Fraction receiving Wajong benefits by diagnosis, cohort and age. Source: Statistics Netherlands Microdata (SSB_AO), own calculations

passed 150,000 in 2006 and is projected to grow to 400,000 and more (van Sonsbeek and Gradus 2006). Consequently, the future of the Wajong has been hotly debated (Besseling et al. 2007; Suijker 2007; Uitvoering Werknemersverzekeringen 2007; Uitvoering Werknemersverzekeringen 2008; Tweede Kamer der Staten-Generaal 2008; OECD 2008; Koning 2009b). Figure 7 shows participation rates by cohort and diagnosis for the years 1999-2005. The percentage receiving Wajong benefits due to mental reasons has risen dramatically for every cohort, while the percentage receiving benefits for all other reasons has remained constant at about half a percent. Benefits granted on the basis of mental problems already surpass $2 \%$ among those who are merely 20 years of age in 2005 .

There are a variety of reasons cited for this (Suijker 2007; Besseling et al. 2007; Uitvoering Werknemersverzekeringen 2007) with three of them recurring most prominently:

1. Substitution effects due to the reform of the General Social Assistance Scheme ('Wet Werk en Bijstand', WWB) in 2004, which shifted fiscal responsibility for this scheme to municipalities. ${ }^{5}$

2. An increase in the number and a shift in the type of conditions in the population.

3 . Increased awareness of the program and better cooperation between specialised educational institutions (Praktijkonderwijs, PRO and Voortgezet Speciaal Onderwijs, VSO) and the UWV / the municipalities.

To our knowledge, there have not been attempts to formally quantify the different mechanisms. From an analysis of hospitalisations by diagnosis, we can practically exclude the possibility that the proportion of individuals with serious mental disorders has increased recently. This is in line with UWV's own analysis (Uitvoering Werknemersverzekeringen 2007), which finds that $85 \%$ of the Wajong awards in 2006 were based on mostly (mild) mental problems and developmental deficits, such as learning disabilities, low levels of cognitive functioning, or symptoms of autism. In our view,

\footnotetext{
${ }^{5} \mathrm{We}$ are grateful to a referee for the suggestion that such a substitution was observed in the U.S., where the caseload of the S.S.I. program (similar in spirit to the Wajong) increased significantly subsequent to welfare reform.
} 
this means that the Wajong program is now more a substitute for general social assistance, rather than a substitute for DI. Considering the focus of this paper, we thus do not analyse the first and the third of the potential reasons for the Wajong growth. Nevertheless, we make two observations.

First, the last paragraph suggests that the current institutional setup is inefficient, as noted before by the OECD (2008) and Koning (2009b): With different institutions (municipalities, UWV / federal government) bearing the financial burden of different programs, program selection will often not be based on the applicants' abilities. Second, the recent developmental literature in economics (Cunha et al. 2006; Cunha and Heckman 2007, 2008; Heckman and Masterov 2007; Heckman 2008) and its ancestors in psychology teach us that many cases of less serious mental problems and developmental deficits are preventable by early intervention in families of low socio-economic status. There are already a number of programs active in The Netherlands that target early childhood health and development. Among them are the Nurse-Family-Partnership (VoorZorg) for young mothers with little education; a program to foster parenting skills in difficult circumstances (Stevig Ouderschap); an adaption of the U.S. High/Scope Perry Preschool Project (Schweinhart et al. 1993, 2005) that aims to improve the learning environment in various ways from age 3 onwards (Kaleidoscoop); and several others. These projects are too recent to facilitate an evaluation of their benefits during adulthood, but outcomes at earlier ages are encouraging. An expansion of these programs seems like the safest bet to raise the productive capacity at the lower end of future cohorts' skill distribution. Still, this is a tentative conclusion since the economic literature on the subject is rather young and large-scale implementation of such programs may be hampered to stigmatisation effects.

\section{Discussion, conclusions, and avenues for future research}

Employment and participation rates of older workers start to decline rapidly after age 45 . In this paper, we highlighted the importance of health in explaining the age related decline in employment and participation rates. The literature on trends in health shows us that longevity increases do not necessarily translate into decreases in morbidity. Studies from the United States demonstrate that in fact, the prevalence of both chronic conditions and disabilities are increasing among the cohorts whose members are up to 50 years of age now. For The Netherlands, we find decreases in the prevalence of disabilities for younger cohorts and constant self-reported health, both conditional on age. Hence, for the near future there is no reason to expect rising rates of individuals on disability rolls because of worsening underlying population health.

One stylised fact from the literature on health and labour outcomes summarised above in Sect. 2.1 is that the correlation is stronger for employment than for earnings. An important avenue for future research is to explore the mechanisms behind this pattern. For example, firms largely protect their workers' earnings from idiosyncratic shocks to firm output (Guiso et al. 2005). Similarly, firms might protect earnings (to some extent) from workers' individual productivity declines resulting from worsening health conditions. Worker-firm matches may dissolve and 
new employment may be difficult to find if health drops below a minimal level. A further necessary condition for this mechanism to be relevant is the absence of complete markets. If markets were complete, risk averse individuals would insure themselves against all idiosyncratic risk. Labour economists have recently explored new approaches of life-cycle welfare measurement under partial insurance, where individuals' earnings evolve stochastically. Health shocks are likely to be behind a substantial amount of the uncertainty, but so far they have hardly been considered as a driving force. There is now a large literature that estimates life-cycle earnings as a stochastic process (MaCurdy 1982; Meghir and Pistaferri 2004) and derives the welfare implications for economic agents (Blundell and Preston 1998; Blundell et al. 2008) under different insurance designs. Low et al. (forthcoming) show for the U.S. that employment risk has a much larger influence on (permanent) earnings than productivity risk has. The graphs we have shown above in Sect. 2 suggest that a large part of permanent employment risk may be due to health reasons and disability insurance. The discussion in Sect. 3.3 suggests that a permanent exit from the labour force through DI may be a substitute for a transitory absence via UI. It would be of great interest to bring these literatures together and derive the welfare implications of different insurance schemes, taking into account UI, DI, and meanstested general social assistance. Low and Pistaferri (2010) undertake a first step in this direction, which seems to us an extremely fruitful approach.

The preceding paragraph takes the perspective that health shocks are inevitable and lays out a research agenda on the design of insurance schemes. But of course, health is malleable to some extent and one may also ask for the potential benefits of better population health in terms of employment. Figures 3 and 4 show that this is the most important path to further increase employment of middle-aged men. Of the 50 (40) year old males who report the worse health category, only about $40 \%$ $(60 \%)$ are at work. In sharp contrast to this, employment rates of men in good health / without a disability are very close to one well into the fifties. In other words, the potential of increasing the participation rates in these groups is very low. Bad health remains the prime candidate for non-participation and policies aimed at increasing the employment rate of middle-aged workers should therefore focus on these. ${ }^{6}$ For females, one may also speculate that the spectacular rises in employment rates evident from Figs. 3 and 4 cannot continue much longer without improving the employment prospects of those with a health problem. In order to design efficient public policy measures, it is very important to understand the precise causal pathways for the low employment prospects of those with health problems. While the answer seems obvious at first sight (improve their health, although this is certainly no easy task), the problem is more subtle because those in poor health differ in important ways from those in good health. We are only just beginning to understand the quantitative importance of direct and indirect effects (Lindeboom et al. 2007). There is a lot of room for research in this area and all conclusions that we draw in the next paragraph are somewhat tentative.

\footnotetext{
${ }^{6}$ For workers nearing retirement age, financial incentives become more important as well. For explaining retirement decisions in these age groups, the relative weight of health reasons and financial incentives remains one of the largest open research questions.
} 
Background characteristics are important for employment rate differences between disabled and non-disabled workers, but studies also indicate that direct effects of the disability on employment are important. Cross-national studies also point out that the impact of a disability varies considerably over countries. This may be related to differences in employment structure, to measures that aim to reduce the employment effects of a disability, but also to social security institutions like the DI system. Indeed, U.S. studies have shown that changes in the generosity and accessibility of the DI program had strong effects on labour force participation rates and the Dutch experience suggests similar patterns. The very recent experience in The Netherlands is an interesting case in this respect. From the point of view of an international comparison, the system was transformed from what probably was the most lenient program with easy access to a much more stringent program where only the severely and permanently disabled qualify for permanent benefits. Accordingly, DI rates have fallen dramatically in the past years, accompanied by substantial increases in the participation rates of 50+ workers. Given the current state of economic research, The Netherlands' DI system now probably comes close to a state-of-the-art in terms of making use of the productive capacity of older workers while providing insurance to those with severe health conditions.

Nevertheless, it remains to be seen whether the positive impact on employment and participation rates will also hold for the future. A substantial share of the WIA applicants with severe conditions is currently given a full but temporary WGA benefit. It is likely that a large share of this group will eventually be labelled as permanently disabled. Vulnerable groups remain, also within the current system. For instance, those who are awarded partial benefits or those who are denied benefits still have health limitations. Increasing employment prospects for these groups is essential and many measures are taken already in this respect. Again, the reforms are too recent as to permit an evaluation at this point. A lot of them, however, are focused on employers which is irrelevant for the increasingly large group of individuals who apply for DI benefits during an unemployment spell. ${ }^{7}$ Another problematic group are those on "Wajong" benefits, but we have argued above that most of them should not be viewed as DI cases but rather fall within the scope of general social assistance. Finally, the pressure on the DI system (as measured in terms of the number of applications) will likely increase substantially if the current economic crisis hits the labour market, constituting a critical test for the effectiveness of recent measures.

Open Access This article is distributed under the terms of the Creative Commons Attribution Noncommercial License which permits any noncommercial use, distribution, and reproduction in any medium, provided the original author(s) and source are credited.

\section{Appendix: Definition of variables}

The data used in Sect. 3.1 stem from the Gezondheidsenquête (1983-1996) and its successor, the 'Permanente Onderzoek Leefsituatie' (POLS, 1997-2005). The data

\footnotetext{
${ }^{7}$ These individuals are known as "vangnetters" in The Netherlands.
} 
are a repeated cross section administered by the Dutch Statistical Office. Annual sample sizes are in the range of 7,000 to 11,000 observations, yielding average cell sizes of around 630 persons in Figs. 1 and 2. In Figs. 3 and 4, cell sizes are obviously smaller, and sometimes considerably so (i.e. for the young in poor health or with a disability, where prevalence is low). The datasets come with standard sampling weights, which we use to construct all of our figures.

Self-assessed health The variable is derived from a standard question on how the respondent would rate his or her health in general. Answers are given on the following response scale (this scale changed in 2001, which is why we use data only for the 18 years until 2000):

1. Very good.

2. Good.

3. Fair.

4. Variable

5. Poor.

We dichotomise the variable in "good health" (top two categories) and "ill health" (bottom two categories).

Activities of daily living We use 8 questions derived from the OECD long-term disability questions (McWhinnie et al. 1982). These question have been consistently asked from 1989 onwards, yielding 17 years of data. The questions include whether the respondent is able to

1. follow normal conversations with three or four other persons,

2. follow normal conversations with another person,

3. read ordinary newsprint,

4. recognise the face of another person from four metres,

5. bite and chew on hard foods,

6. carry an object of five kilogrammes for ten metres,

7. bend down while standing to pick up a shoe,

8. walk for 400 metres without resting.

For each of these questions, answers could be given on the following scale: "no problem / light problem / medium problem / severe problem". We give these categories the scores " 0 / 1 / 2 / 3" and, for the purposes of the above analyses, define the cutoff for suffering from a disability for a score of at least 4 .

Labour force status Whether an individual reported to be working or not in the survey.

\section{References}

Autor, D. H., \& Duggan, M. G. (2003). The rise in the disability rolls and the decline in unemployment. Quarterly Journal of Economics, 118(1), 157. 
Autor, D. H., \& Duggan, M. G. (2006). The growth in the social security disability rolls: A fiscal crisis unfolding. Journal of Economic Perspectives, 20(3), 71-96.

Banks, J., Emmerson, C., \& Tetlow, G. (2007). Healthy retirement or unhealthy inactivity: How important are financial incentives in explaining retirement? (Mimeo). Institute for Fiscal Studies, London.

Berthoud, R. (2008). Disability employment penalties in Britain. Work, Employment \& Society, 22(1), 129-148.

Besseling, J., Hagen, B., Andriessen, S., te Peele, A., Crone, M., Kok, L., \& de Vos, E. (2007). Toename gebruik ondersteuning voor jongeren met een gezondheidsbeperking (tNO Rapport No. 385), available www.tno.nl.

Bhattacharya, J., Choudhry, K., \& Lakdawalla, D. N. (2008). Chronic disease and severe disability among working-age populations. Medical Care, 46(1), 92-100.

Black, D., Daniel, K., \& Sanders, S. (2002). The impact of economic conditions on participation in disability programs: Evidence from the coal boom and bust. American Economic Review, 92(1), 27-50.

Blundell, R. W., \& Preston, I. (1998). Consumption inequality and income uncertainty. Quarterly Journal of Economics, 113(2), 603-640.

Blundell, R. W., Pistaferri, L., \& Preston, I. (2008). Consumption inequality and partial insurance. American Economic Review, 98(5), 1887-1921.

Bound, J., \& Burkhauser, R. V. (1999). Economic analysis of transfer programs targeted on people with disabilities. In O. C. Ashenfelter \& D. Card (Eds.), Handbook of labor economics (Vol. 3, pp. 34173528). Amsterdam: Elsevier, Chap. 51.

Bound, J., \& Waidmann, T. (2002). Accounting for recent declines in employment rates among workingaged men and women with disabilities. The Journal of Human Resources, 37(2), 231-250.

Case, A., \& Paxson, C. (2005). Sex differences in morbidity and mortality. Demography, 42(2), 189-214.

Crimmins, E. M., Reynolds, S. L., \& Saito, Y. (1999). Trends in health and ability to work among the older working-age population. Journal of Gerontology, Series B, 54(1), S31-S40.

Cunha, F., \& Heckman, J. J. (2007). The technology of skill formation. American Economic Review, 97(2), $31-47$.

Cunha, F., \& Heckman, J. J. (2008). Formulating, identifying and estimating the technology of cognitive and noncognitive skill formation. Journal of Human Resources, 43(4), 738-782.

Cunha, F., Heckman, J. J., Lochner, L., \& Masterov, D. V. (2006). Interpreting the evidence on life cycle skill formation. In E. Hanushek \& F. Welch (Eds.), Handbook of the economics of education (Vol. 1, pp. 697-812). Amsterdam: Elsevier.

Currie, J., \& Madrian, B. C. (1999). Health, health insurance and the labor market. In O. C. Ashenfelter \& D. Card (Eds.), Handbook of labor economics (Vol. 3, pp. 3309-3416). Amsterdam: Elsevier, Part 3, Chap. 50 .

de Jong, P. (2008). Recent changes in Dutch disability policy (Mimeo). University of Amsterdam.

de Jong, P., \& Thio, V. (2002). Donner versus Veldkamp: over nut en nadeel van gedeeltelijke waouitkeringen (aPE-report 53).

de Jong, P., Thio, V., \& Barteling, H. (2005). Uwv als poortwachter (aPE report 127).

de Jong, P., Lindeboom, M., \& van der Klaauw, B. (forthcoming). Screening disability insurance applications. Journal of the European Economic Association.

Duggan, M., \& Imberman, S. (2006). Why are the disability rolls skyrocketing? The contribution of population characteristics, program changes and economic conditions. In D. Cutler \& D. A. Wise (Eds.), Health in older ages: The causes and consequences of declining disability among the elderly. Chicago: University of Chicago Press.

García-Gómez, P. (2008). Institutions, health shocks and labour outcomes across Europe (Documento de Trabajo 2008-01 FEDEA).

García-Gómez, P., \& López Nicolás, A. (2006). Health shocks, employment and income in the Spanish labour market. Health Economics, 15, 997-100.

Guiso, L., Pistaferri, L., \& Schivardi, F. (2005). Insurance within the firm. Journal of Political Economy, 113(5), 1054-1087.

Heckman, J. J. (2008). Schools, skills, and synapses. Economic Inquiry, 46(1), 1.

Heckman, J. J., \& Masterov, D. V. (2007). The productivity argument for investing in young children. Review of Agricultural Economics, 29(3), 446-493.

HMD (2009). Human mortality database. http://www.mortality.org.

Kapteyn, A., Smith, J. P., \& van Soest, A. (2007). Vignettes and self-reports of work disability in the united states and the netherlands. American Economic Review, 97(1), 461-473.

Kerkhofs, M., Lindeboom, M., \& Theeuwes, J. (1999). Retirement, financial incentives and health. Labour Economics, 6(2), 203-227. 
Koning, P. W. C. (2009a). Experience rating and the inflow into disability insurance. De Economist, 157(3), 315-335.

Koning, P. W. C. (2009b). Herbezinning op onderkant arbeidsmarkt. Economisch Statistische Berichten, 94(4551), 24-25.

Koning, P. W. C., \& van Vuuren, D. J. (2010). Disability insurance and unemployment insurance as substitute pathways. Applied Economics, 42(5), 575-588.

Kreider, B., \& Riphahn, R. T. (2000). Explaining applications to the U.S. disability system: A semiparametric approach. The Journal of Human Resources, 35(1), 82-115.

Lakdawalla, D. N., Bhattacharya, J., \& Goldman, D. P. (2004). Are the young becoming more disabled? Health Affairs, 23(1), 168-176.

Lechner, M., \& Vazquez-Alvarez, R. (2004). The effect of disability on labour market outcomes in Germany: Evidence from matching (cEPR Discussion Paper 4223).

Lindeboom, M. (2006). Health and work for older workers. In A. M. Jones (Ed.), The Elgar companion to health economics (pp. 26-35). Cheltenham: Edward Elgar, Chap. 3.

Lindeboom, M., Llena Nozal, A., \& van der Klaauw, B. (2007). Health shocks, disability and work (Netspar Discussion Paper 11/2007-026).

Low, H. W., \& Pistaferri, L. (2010). Disability risk, disability insurance, and life-cycle behavior (nBER Working Paper 15962).

Low, H. W., Meghir, C., \& Pistaferri, L. (forthcoming). Wage risk and employment risk over the life cycle. American Economic Review.

MaCurdy, T. E. (1982). The use of time series processes to model the error structure of earnings in a longitudinal data analysis. Journal of Econometrics, 18(1), 83-114.

McWhinnie, J. R., Törnudd, P., Ås, D., \& Pelli, C. (1982). Measuring disability (5th ed.). OECD Social Indicator Development Programme, Special Studies, Paris: OECD.

Meghir, C., \& Pistaferri, L. (2004). Income variance dynamics and heterogeneity. Econometrica, 72(1), $1-32$.

Møller Danø, A. (2005). Road injuries and long-run effects on income and employment. Health Economics, 14(9), 955-970.

OECD (2008). Sickness, disability and work: Breaking the barriers: Vol. 3. Denmark, Finland, Ireland and The Netherlands. Paris: OECD Publishing.

OECD (2009). Employment outlook 2009: Tackling the jobs crisis. Paris: OECD Publishing.

Oeppen, J., \& Vaupel, J. W. (2002). Broken limits to life expectancy. Science, 296(5570), 1029-1031.

Parsons, D. O. (1991). Self-screening in targeted public transfer programs. Journal of Political Economy, 99(4), 859.

Riphahn, R. T. (1999). Income and employment effects of health shocks a test case for the German welfare state. Journal of Population Economics, 12(3), 363-389.

Schweinhart, L. J., Barnes, H. V., \& Weikart, D. P. (1993). Significant benefits: The high/scope Perry preschool study through age 27. Ypsilanti: High/Scope Press.

Schweinhart, L. J., Barnett, W. S., \& Belfield, C. R. (2005). Lifetime effects: The high/scope Perry preschool study through age 40. Ypsilanti: High/Scope Press.

Stapleton, D. C., Coleman, K. A., Dietrich, K. A., \& Livermore, G. A. (1998). Econometric analyses of DI and SSI application and award growth. In K. Rupp \& D. C. Stapleton (Eds.), Growth in disability benefits explanations and policy implications. Kalamazoo: W. E. Upjohn Institute for Employment Research.

Suijker, F. W. (2007). Verdubbeling van de instroom in de wajong: Oorzaken en beleidsopties. Netherlands Bureau for Economic Policy Analysis, CPB Document 156.

Tweede Kamer der Staten-Generaal (2008). Wijziging van de wet arbeidsongeschiktheidsvoorziening jonggehandicapten in verband met het bevorderen van de participatie van jonggehandicapten door werk en arbeidsondersteuning (Memorie van Toelichting). Kamerstukken 31780, no. 3.

Uitvoering Werknemersverzekeringen (2007). De groei van de wajonginstroom (Kenniscahier 07-01).

Uitvoering Werknemersverzekeringen (2008). De participatiemogelijkheden van de wajonginstroom (Kenniscahier 08-01).

van Kippersluis, H., O’Donnell, O., van Doorslaer, E., \& van Ourti, T. (2010). Socioeconomic differences in health over the life cycle in an egalitarian country. Social Science \& Medicine, 70(3), 428-438.

van Sonsbeek, J.-M., \& Gradus, R. H. J. M. (2006). A microsimulation analysis of the 2006 regime change in the Dutch disability scheme. Economic Modelling, 23, 427-456. 